\author{
Tetyana Vitenko ${ }^{1}$ and Yaroslav Gumnitsky ${ }^{2}$
}

\title{
KINETIC LAWS OF FLAVONOID EXTRACTION FROM MULBERRY LEAVES BY EXTRACTANT CAVITATION ACTIVATION
}

\author{
IIvan Puluj Ternopyl National Technical University, \\ 56, Ruska str., 46001 Ternopyl, Ukraine; vitenko@tstu.edu.ua \\ 2Lviv N ational Polytechnic University, 12, S. Bandera str., 79013 Lviv, Ukraine
}

Received: December 01, 2010 / Revised: J anuary 26, 2011 / Accepted: M arch 12, 2011

(C) Vitenko T., Gumnitsky Y., 2011

\begin{abstract}
Mass transfer in a capillary-porous body-liquid extraction, on condition that an activated and unactivated extractant is used, has been experimentally investigated. The mechanism of the extraction process for extracting the desired components from mulberry leaves has been found. Experimental results are generalized on the base of a mathematical model that allows the process to be predicted when implementing it in practice.
\end{abstract}

Keywords: extraction, cavitation activation, plant ran material, intensification

\section{Introduction}

The recent progress achieved in the study of the role of biologically active substances (phenolic), their influence on metabolism, physiological functions led to their wide application in pharmacy. This is explained by a wide spectrum of a biological action of plants. The mulberry is a valuable source of biologically active substances: tannins, flavonoids (oxalic, malic, tartaric, citric, amber, and other acids), steroids and their derivatives, vitamins $\mathrm{C}, \mathrm{B}_{1}, \mathrm{~B}_{2}$, PP and carotene, higher fatty acids. Taking into consideration the unique chemical composition of the mulberry and century-old experience of using it in folk medicine, present-day researches develop mulberry-based medical preparations and biologically active additives.

A specific feature of the processes for their production is long run time of several hours and even days. Another characteristic feature is low technological level of their implementation. Unfortunately, at the majority of chemical-and-pharmaceutical enterprises, the processes of extraction from the plant raw material are implemented in the batch apparatus by using a multipledegree counter-current infusion (percolation) and even a simple infusion (maceration). One more feature of these processes is low degree of extraction of the desired components from the plant raw material. Therefore, frequently, in production of phytochemical preparations, a great quantity of biologically active substances occurs in waste. One of the perspective ways for obtaining the extractive preparations is the use of the extractant activation [1-5]. The authors have obtained [1-4] a new extractant (electrically activated water system) by treating softened drinking water in the electro-dialysis membrane units. In the work [5] it is proposed to carry out electrochemical activation of water.

The positive results have been obtained relative to the increase in the efficiency of extracting the phenolic compounds from Valerianae officinal's by using the extractant activated in hydrodynamic cavitation units [6, 7]. The proposed method has the advantages over the extraction method such as vortex [8], application of rotorpulsation apparatus [9-11]. The disadvantages of the mentioned methods are considerable grinding of the raw material and wash-out of high-molecular substances from the destructed cells. Usually they obtained extracts with ballast and a great content of fine-disperse phase (dregs). Such extracts require settling time of several days or they must be undergo to centrifuging, and the available ballasts decrease their application time and make the cleaning difficult. Note rather high power consumption and destruction of the unit components by erosive action. They are unreliable, and this is peculiar to the units and apparatus using the components rotating at a high speed and requiring fine balancing.

Thus, the purpose of the work was the experimental investigation of the mass transfer in the solid body-liquid system using the un-activated extractant and the extractant activated in the hydrodynamic cavitation unit.

\section{Experimental}

In the process of obtaining the infusion, we used non-pharmacopoeia raw material, namely, mulberry 
leaves, and also auxiliary substances widely used in pharmaceutical practice. When studying the properties of the obtained infusions, we used the generally accepted methods of organoleptic, technological, physical-andchemical, biological investigations allowing to objectively estimate their quality on the base of the obtained and statistically processed results.

Activation of the extractant was implemented in the static cavitation unit [12]. Processing conditions were chosen with taking into consideration the previous results [6]. For the investigations we used the plant raw material of various sizes. The fractional composition obtained by a sieve analysis method is shown in Fig. 1 as the distribution function $F(\mathrm{~m})$ versus particle size of relationship.

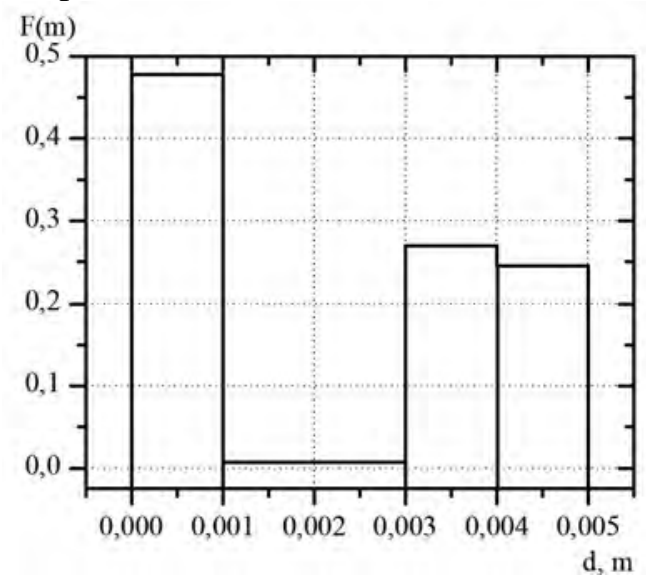

Fig. 1. Distribution histogram for mulberry leaves distributed by sizes

The polydisperse fraction of the plant raw material was subdivided into groups of raw material with the particles: 1) < $1 \mathrm{~mm}$; 2) 3-4 mm; 3) 4-5 mm. Fraction 1$3 \mathrm{~mm}$ was not considered due to its small part in the mixture (0.07). The experimental technique was as follows. After warming up of the thermostat to a required temperature, a glass reactor of $1 \mathrm{dm}$ was placed in it; the reactor was filled with the plant raw material of a certain fraction and an activated or standard $70 \%$ spirit was added. A solid-to-liquid mass ratio was 1:10. In extracting, a constant temperature of $T=(293 \pm 0.5) \mathrm{K}$ was maintained. In certain time intervals, liquid-phase samples were taken for the analysis. The content of the desired components was determined by the spectrophotometric analysis method.

\section{Results and Discussion}

The results of extracting the extractive substances to the equilibrium state depending on the sizes of the particles are presented in Table 1.

\section{Content of the desired components in the extractant}

\begin{tabular}{|c|c|c|}
\hline \multirow{2}{*}{$\begin{array}{c}\text { Raw } \\
\text { material } \\
\text { diameter, } \\
\text { mm }\end{array}$} & Tannins, \% & Total of flavonoids, \% \\
\cline { 2 - 3 } & & $3.56 \pm 0.01$ \\
\hline $\begin{array}{c}\text { Ungrinded } \\
\text { raw material }\end{array}$ & $8.61 \pm 0.02$ & \\
\hline & $8.72 \pm 0.1$ & $4.34 \pm 0.02$ \\
\hline 1 & $8.68 \pm 0.01$ & $4.08 \pm 0.02$ \\
\hline $3-4$ & $8.54 \pm 0.03$ & $3.86 \pm 0.02$ \\
\hline $4-5$ &
\end{tabular}

The obtained data indicate a negligible influence of the grinding degree for the given raw material on the extraction process for extracting the acting substances. Furthermore, dried mulberry leaves are rather brittle and spontaneously ground in loading. At the same time, grinding of the plant raw material causes increase in the mass-transfer surface and destroying of barriers on the way of transition of the desired components from the solid phase to the liquid one. On the other hand, the particle sizes and form are important for calculation of the coefficients which characterize the external and internal mass transfer. Note that in general the extraction process runs by a mixed mechanism at the start of the process (region I) and the internal diffusion mechanism at the end of the process (region II). The analysis of the curves (Fig. 2) confirms the existence of the mixed mechanism of the extraction process.

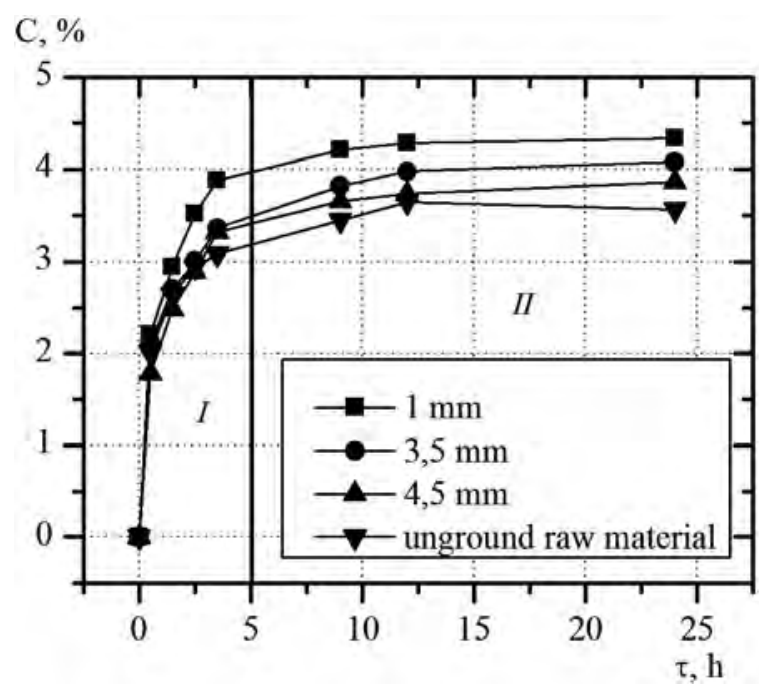

Fig. 2. Concentration of flavonoids in the extractant $v s$ time 
The plot in Fig. 3 shows the kinetics of the extraction of similar fractions for the case when the activated extractant is used.

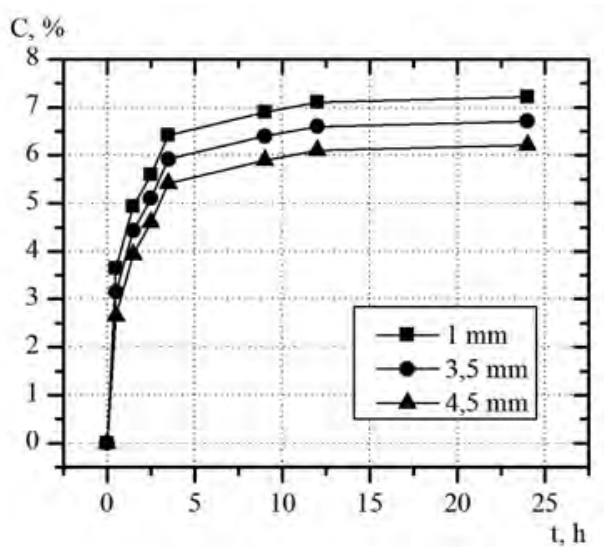

Fig. 3. Concentration of flavonoids in the activated extractant $v s$ time

As the investigation results show, the quantitative content of the sum of flavonoids in the recalculation for rutin in the activated extractant (mulberry leaves infusion) is significantly greater than in the un-activated extractant on condition that a similar raw material is used. The intensity of the extraction by a cavitated extractant is significantly higher than in the case of the uncavitated extractant. For a quantitative comparison of the masstransfer characteristics of the external and internal mass transfer, we calculate the appropriate coefficients. The condition for this calculation is that the highest resistance to the transition of the desired component to the main extractant mass is created by the cell membrane, and the mass-transfer area equals to the surface area of the plant raw material particle pores, but not the outer surface area, and it can be determined as a ratio of the outer surface area of the solid-phase particle $F_{0}$ to the particle porosity value of $\varepsilon$ [13]. Then the quantity of the desired component, being extracted from the solid phase for a time interval of $\tau$, is determined by the expression:

$$
-V \frac{d C}{d \tau}=k \frac{F_{0}}{\varepsilon}\left(C-C_{1}\right)
$$

where $k$ is the mass-transfer coefficient, $\mathrm{m} / \mathrm{s} ; V$ is the internal cell volume, $\mathrm{m}^{3} ; C$ is the variable concentration of the desirable component in the solid-phase cells, $\mathrm{kg} / \mathrm{m}^{3}$; $C_{1}$ is the concentration of the desired component in the extractant, $\mathrm{kg} / \mathrm{m}^{3}$.

Another relationship is obtained from the material balance equation:

$$
W\left(C_{1}-C_{n}\right)=V\left(C_{0}-C\right)
$$

where $W$ is the extractant volume, $\mathrm{m}^{3} ; C_{n}$ is the initial extractant concentration $\left(C_{n}=0\right) ; C_{0}$ is the initial concentration of the desired component in the solid-phase cells, $\mathrm{kg} / \mathrm{m}^{3}$.
The solution of the system of Eqs. (1) and (2), allowing for the equilibrium conditions of $C=C_{1}=C_{1 e q}$, is expressed by:

$$
1-\frac{C_{1}}{C_{\text {leq }}}=\exp \left(-\frac{k \cdot F_{0}(1+\beta)}{V \cdot \varepsilon}\right) \cdot \tau
$$

where $C_{1 e q}$ is the equilibrium concentration of the desired component in the extractant, $\mathrm{kg} / \mathrm{m}^{3} ; \beta=V / W$.

Eq. (3) in logarithmic coordinates describes a straight line by which slope the mass-transfer coefficient $k$ can be determined. The obtained experimental values of the concentrations of the desired component in the extractant and equilibrium concentrations were substituted into the equation:

$$
\lg \left(1-\frac{C_{1}}{C_{1 e q}}\right)=-k^{*} \cdot \tau
$$

where $k^{*}=\frac{0.434 \cdot k \cdot F_{0} \cdot(1+\beta)}{V \cdot \varepsilon}$

The calculation results for the extraction processes, using the $70 \%$ spirit under standard conditions and the activated extractant for the particles $<1 \mathrm{~mm}$, are given in Fig. 4.

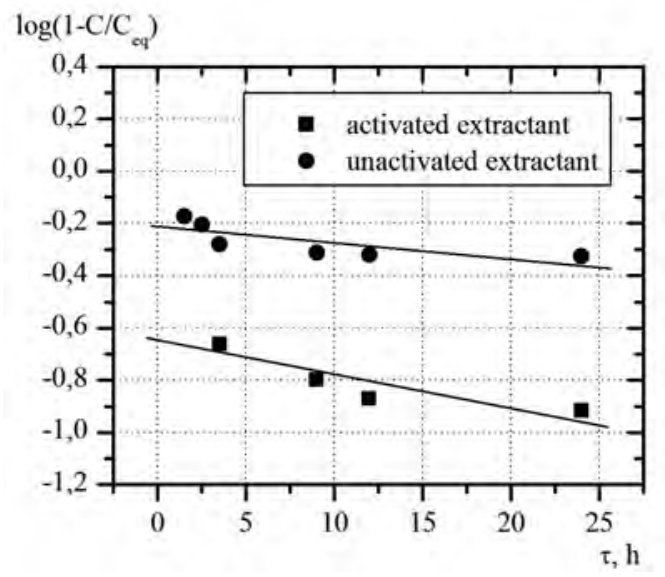

Fig. 4. Extraction $\log \left(1-C / C_{e q}\right)$ vs extraction time

Further processing of the obtained results was performed with taking into consideration the fact that the porosity is the ratio of the void volume $U_{0}$ in the solidphase particle to its total volume $U: \varepsilon=\frac{U_{0}}{U}$ and $\beta$ in Eq. (4) with allowing for the equilibrium conditions was determined as $\beta=\frac{C_{1 e q}}{C_{0}-C_{1 e q}}$. Due to the fact that the solid-phase particles have a small size, they can be consi dered to be ball-shaped. Then for a single particle a valid ratio is as follows:

$$
\frac{F_{0}}{\varepsilon}=\frac{5.33 \pi^{2} \cdot R^{5}{ }_{\text {avg }}}{U_{0}}
$$


Calculation of mass-transfer coefficients

\begin{tabular}{|c|c|c|c|c|c|c|}
\hline Raw material and extractant characteristic & $U_{0}, \mathrm{~m}^{3}$ & $\beta$ & $R_{\text {avg }}, \mathrm{m}$ & $m, \mathrm{~kg}$ & $k^{*}, 1 / \mathrm{s}$ & $k, \mathrm{~m} / \mathrm{s}$ \\
\hline Unactivated extractant $\left(d_{\text {avg }}<1 \mathrm{~mm}\right)$ & $3.318 \cdot 10^{-10}$ & 0.513 & $0.5 \cdot 10^{-3}$ & $6.28 \cdot 10^{-7}$ & $1.6 \cdot 10^{-6}$ & $2.97 \cdot 10^{-9}$ \\
\hline Activated extractant $\left(d_{\text {avg }}<1 \mathrm{~mm}\right)$ & $3.318 \cdot 10^{-10}$ & 1.78 & $0.5 \cdot 10^{-3}$ & $6.28 \cdot 10^{-6}$ & $3.17 \cdot 10^{-6}$ & $5.93 \cdot 10^{-9}$ \\
\hline
\end{tabular}

For the total mass of the raw material, subjected to the extraction, the equation can be written as:

$$
\frac{F_{0}}{\varepsilon}=\frac{5.33 \pi^{2} \cdot R^{5}{ }_{\text {avg }} \cdot M}{U_{0} \cdot m}
$$

where $M$ is the solid-phase mass loaded for the extraction; $m$ is the mass of a single particle; $R_{\text {avg }}$ is an average radius of the solid-phase particle. Then the equation for determination of the mass-transfer coefficient $k$ will have the form:

$$
k=\frac{k^{*} \cdot W \cdot U_{0} \cdot m \cdot \beta}{22.8 R_{\text {avg }}{ }^{5} \cdot M \cdot(1+\beta)}
$$

The calculation results are presented in Table 2.

From the data of Table 2, it is seen that the coefficient of the external and internal mass transfer, on condition that the activated extractant is used, exceed similar characteristics, provided that the unactivated extractant is used. Intensification of the external and internal mass transfer is first related to the extractant structure change. We consider the mechanism of the liquid-phase cavitation activation. As an example, let us examine water, $30 \%$ of which is contained in the extractant. According to the theoretical statements of the water molecular structure, because of an asymmetric distribution of positive and negative charges inside the water molecule, their electric centres do not coincide. This causes forming of a molecule with two unlike charge poles, i.e. a dipole. The polar dipole strength is expressed in terms of the dipole moment: $\mu=e \cdot l$. For water, the dipole moment is $1.84 \cdot 10^{-18}$ esu.

The water treated by cavitation is enriched with a sufficient quantity of monomer molecules, free radicals, i.e. atoms and clusters of atoms with an unpaired electron. Such active particles are attracted to a positive pole of the water dipole by their unpaired electron, increasing its dipole moment by the electron charge value $\left(4.803 \cdot 10^{-10} \mathrm{esu}\right)$. This causes the increase in the activity of such so called hydrogen bonds (the latter occur between unlike poles of the neighboring dipoles, and this results in the formation of the associations of water molecules that are as if joined onto each other). Thus, the water, treated by cavitation, loses its spatial structure, and its dipoles, activated by free radicals, become free and more active [14].

\section{Conclusions}

The extraction process mechanism for extracting the desired components from the mulberry leaves has been established. It is shown that in extracting of the desired components from the ground raw material causes a negligible increase in the extraction process rate.

The intensification of both the external and the internal mass transfer has been confirmed on the base of the mathematical generalization of the experimental results.

\section{References}

[1] Gulyi I., Bobrovnyk M., Kupchyk M. et al.: Pishchevaja Promyshlennost, 1993, 11, 19.

[2] Donchenko L., Karpovych N. and Simkhovych E.: [in:] Karpovych N. (Ed.), Proizvodstvo Pektina. Kishinev 1993.

[3] Nelina V., Donchenko L. and Karpovych N.: Hranenie i Pererabotka Selhozsyria, 1994, 3, 15.

[4] Kupchyk M. Chuk V., Kupchyk L. and Kartel M.: Harchova i Pererobna Promyslovist, 2003, 6, 20.

[5] Kupchyk M., Chuk V. and Bogdanov E.: Harchova Promyslovist, 2003, Dodatok do 3, 20.

[6] Vitenko T.: Voprosy Khimii i Khimicheskoi Techn., 2007, 3, 147.

[7] Vitenko T.: Voprosy Khimii i Khimicheskoi Techn., 2006, 3, 153.

[8] Melichar M., Rusek V. and Solich Y.: Ceskosl. Farmac., 1954, 10, 336 .

[9] Lekveishvili M., Balabudkin M. et al.: Khim.-Farm. Zh., 1983, 17, 354.

[10] Sosnina N., Mironov V. and Konovalov A.: Hranenie i Pererabotka Selhozsyrja, 1999, 6, 32.

[11] Zaporozhec E., Bogus A. and Jahutl M.: Vestnik Ros. Akad. Selskohozjajstvennyh Nauk, 1998, 1, 84.

[12] Vitenko T.: Gidrodynamichna Kavitacija u Masoobminnyh, Khimichnyh i Biologichnyh Procesah. V-vo TDTU im. I. Puljuja, Ternopil 2009.

[13] Djachok V.: Khim. Promyslovist Ukrainy, 2001, 4, 52.

[14] Vitenko T. and Gumnitsky Ya.: Khimija i Techn. Vody, 2007, 5,422 .

\section{КIНЕТИЧНІ ЗАКОНОМІРНОСТI ЕКСТРАГУВАННЯ ФЛАВАНОЇДІВ 3 ЛИСТЯ БІЛОЇ ШОВКОВИЦІ ІЗ ЗАСТОСУВАННЯМ КАВІТАЦЙНОЇ АКТИВАЦІЇ ЕКСТРАГЕНТА}

Анотація. Експериментально досліджено масообмін при екстрагуванні в системі капілярно-пористе тіло - рідина за умов використання активованого і неактивованого екстраагента. Встановлено механізм процесу вилучення цільових компонентів з листя шовковииі білої. Експериментальні результати узагальнені на основі математичної моделі, щุо дає змогу прогнозувати процес під час його реалізації на практиці.

Ключові слова: екстракиійне вилучення, кавітаційна активачія, рослинна сировина, інтенсифікація. 